\title{
Testing Mediation of Psychological Empowerment, Work Engagement to Affective Commitment to Change
}

\author{
Susilo $^{1, *}$, Wustari L. Mangundjaya ${ }^{1}$ \\ ${ }^{I}$ Faculty of psychology Universitas Indonesia Depok, West Java, Indonesia \\ "Corresponding author.Email:Susilo62@ui.ac.id,wustari@ui.ac.id
}

\begin{abstract}
One of the causes of failure in the change process is the lack of commitment from individuals in the organization. This study proposes to explore the relation of the two variables, namely psychological empowerment, work engagement on affective commitment to change. We also tested the mediation effect of psychological empowerment on the relationship between work engagement to affective commitment to change. An online survey questionnaire was used to collect data $(\mathrm{N}=190)$ of the airport company on operation unit non-aeronautical. SPSS has used to analyze the data in this study using Pearson's Correlation, and Hayes Process Macro v.3.0. The results of this study showed that the two variable have significant correlation on affective commitment to change, but mediation effect of psychological empowerment did not influence on work engagement and affective commitment to change.
\end{abstract}

Keywords: psychological empowerment, work engagement, resistance to change

\section{INTRODUCTION}

Organizational change is an effort to change the condition to a better organization in the future. Indonesia, the issue of making organization changes is important, where the Government of Indonesia has instructed all organizations, particularly state-owned companies to carry out many transformational programs in response demands for the environmental changes [1]. In the process of change and the development of organizational excellence to be able to compete can also create a dilemma in the process of implementing innovation and bureaucratic control [2]. Organizational change is not always successful; in fact, many have failed to achieve expected goals. Failure to implement organizational change can result in greater expense than the benefits received by the organization [3]. Therefore, failures in change process need to be avoided, one of which is by considering commitment to changes in employees. According to Herscovitch \& Meyer one of the causes of failure in the change process is the lack of commitment from individuals in the organization [4].

Failures in the change process can become the caused of lack employee commitment and lack of communication from superiors in carrying out the change program [5]. Affective commitment is also influenced by perceptions of superiors' support [6], transformational leadership and selfefficacy [7], and several other variables such as trust, empowerment and leadership [1]. Furthermore, the factors that influence the increase in commitment to change in employees were: change communication, trust in the organization, superior-subordinate relations [8], [9].

Other factor that influenced the commitment to change is work engagement [10]. Increasing engagement with employee commitment has always been the focus of the
HR Department [11]. From the employee side, engagement is related to ways of thinking, feeling and acting positively [12]. In this regard, the engagement of each employee is one of the keys in which the basic elements that help the organization survive are individuals. Employees who have high work engagement, have a great influence on their work and become very attached to their work [13]. Conversely, employees who have low work engagement can experience a decrease in enthusiasm and enthusiasm due to fatigue, dislike of work and increased turnover intention [14].

Psychological empowerment is one of the source in competitive advantage, where it is a corporate strategy in improving performance and developing organizations that are flexible, adaptable to changes in the external environment [15]. In the concept of empowerment, employees are given the opportunity and flexibility to empower themselves in the hope that they will be able to engage in the targets set by the company. Therefore, psychological empowerment for employees is expected to develop a commitment to change.

Further, literature about the process of increasing company psychological empowerment have showed that it could increasing productivity or performance, employee motivation, job satisfaction, and work success [16], [17], [18]. Psychological empowerment and affective commitment to change were important factors in the organizational change and it is a continuous contribution from employees. Therefore, employee commitment is critical and is assumed to be done through increasing psychological empowerment and affective commitment to change [19]. The purpose of this study was to 1) examine the relationship between work engagement and affective commitment to change, 2) examine the work engagement relationship to psychological empowerment, 3) test the role of psychological empowerment mediation in the 
relationship between work engagement and affective commitment to change.

\section{LITERATURE REVIEW}

\subsection{Affective Commitment to Change}

According to Herscovitch \& Meyer, commitment to change is a mind-set of individuals who move it to take actions that are deemed necessary to successfully implement the change process [4]. Commitment to change consists of 3 dimensions, namely (1) affective commitment to change, described as the desire of individuals to provide support for changes that occur on the basis of a belief in the benefits that will be received from the change; (2) continuous commitment to change, described as the desire of individuals to provide support for changes that occur on the basis of a sense of obligation; (3) normative commitment to change, as a form of obligation insight to individuals in supporting a change, continuance commitment to change is defined as a form of recognition in support of change because there will be costs when failures occur. Affective commitment to change is different from normative commitment to change because normative commitment to change is based more on moral considerations to participate in change initiatives including the existence of appropriate rules. Continuance commitment, normative commitment, and affective commitment have fundamental differences [4]. Continuance commitment to change arises because it is based on the consideration of profit and loss in supporting change [4]. Therefore, continuous commitment to change and normative commitment to change arises not based on individual energy and positive emotions. Further, previous studied showed that the implementation change in an organization is well affected by commitment to change, especially in affective commitment to change [20]. Furthermore, affective commitment to change is considered to represent a commitment to change in general [21]. This is due to affective commitment that has benefits in accelerating organizational change, emotional attachment of workers, facilitating individual learning, and improving performance [22], [4].

\subsection{Work engagement}

The organization current development, ensuring employee work engagement is very important with the characteristics of employees must be passionate, dedicated, and absorbed into their daily work [23], [24]. From the employee side, engagement is related to ways of thinking, feeling and acting positively [12]. Work engagement is defined as a positive condition, the fulfillment of affective motivation with the characteristics of Vigor, dedication and absorption [25]. Bell and Barkhuizen describe the dimension characteristics of work engagement (a) vigor as a level of energy and mental endurance at work, willingness to invest effort in work and persistence in the face of difficulties, (b) dedication as a sense of importance, enthusiasm, inspiration, pride and challenge, and (c) absorption as a form of doing work in totality with pleasure and it is difficult to get away from work [26]. The engagement of each employee is one of the keys in which the basic elements that help the organization survive are individuals [27].

Employees who have work engagement have a high sense of trust in the organization so that it will add meaning to its existence in the organization and show a higher level of commitment to the organization [28]. Research conducted by Albrecht and Andreetta shows that engagement has a direct influence on affective commitment to change [29]. In addition to this, work engagement has a positive impact on increasing productivity and functionality in the company [30].

\subsection{Psychological Empowerment}

Empowerment describes the processes associated with the work environment and organization as well as related to individuals namely cognition, perception, and attitudes in influencing employee behavior [31]. Khan said that empowerment is an interpersonal relationship that is supported to build trust between employees and management [32]. Psychological empowerment described as a psychological condition of a person in his ability to complete work [18]. Psychological empowerment consists of four dimensions: meaning, competence, selfdeterminant, and impact [33]. Meaning is the value of goals or work goals as assessed by an individual's perception relative to own personal mission or expectations. In the context of the work environment, meaningfulness is defined as the value of the goals or work objectives, valued concerning to an id belonging to each of them [34]. Meaning is the result of the feeling that the task done is something valuable and makes a difference. Activities undertaken in harmony with self-concept in individuals must be linked to more meaningful work experience. Employee empowerment efforts are carried out to get greater meaning from the work done [35]. Restoration meaning in work is seen as a way to foster attachment to work [36], [37]. Self-determination is an individual's feeling of choice in initiating and organizing action [33] Self-endorsed goals will enhance employee engagement, while heteronomous goals, even when introduced efficaciously, will not [38]. Goals that are selected through self-determination are well-internalized and autonomous [39]. Competence refers to specific self-efficacy for work; that is, the ability of individuals to carry out work activities with the necessary skills and knowledge [33]. Feelings of competence and confidence are related to respect to achieve goals associated with increased intrinsic motivation and well-being [38]. Self-efficacy on employees who have a feeling of being engaged will see themselves able to fully handle the demands of their work [40]. There is a strong correlation between self-efficacy and engagement [41]. 
Impact is the extent to which a person can influence the strategic, administrative or operating results at work [33]. Impacts indicate organizational involvement and illustrate how individuals feel that they make a difference in their organizations [42].

\subsection{The relationship between psychological empowerment, work engagement and commitment to change}

Psychological empowerment and affective commitment to change are mostly orthogonal reactions, where psychological empowerment is more affected by beliefs about support, while affective commitment to change is shaped more by beliefs about need and legitimacy [19]. Psychological empowerment is done to improve employees' feelings of self-efficacy by identifying conditions that foster helplessness [43]. At work, psychological empowerment is associated with increased commitment, increased quality and innovation [44]. According to Zeffane and Zarooni psychological empowerment influenced on commitment to change [45]. The relationship between these two variables was also supported by research conducted by [46] which stated that psychological empowerment was positively correlated to commitment to change. In this study, the researchers will look at the relationship between psychological empowerment and affective commitment to change. Based on the discussion, the first hypothesis as follows:

Hypothesis 1: Psychological empowerment is positively related to affective commitment to change.

Impact in psychological empowerment concept, implies involvement and reflects whether individuals feel that they make a difference in their organization [42]. Impact implies a sense of progress toward individual goals and beliefs that their actions make a difference in their organization, which contributes to employee involvement [47]. Studies have found that psychological empowerment is a significant predictor of work engagement [47], [48]. Based on this discussion the following is the second hypothesis.

Hypothesis 2: work engagement is positively related to Psychological empowerment

Work engagement is a significant factor in the relationship between employees' well-being and organizational commitment [49]. Previous research also showed that the affective commitment to change was considered to be the most critical element of organizational commitment [11]. Based on this discussion, the following hypothesis propose:

Hypothesis 3: work engagement is positively related to Affective commitment to change

Psychological empowerment has a relationship with work engagement and affective commitment to change, where work engagement also has a direct relationship with affective commitment to change.
Hypothesis 4: Psychological empowerment mediate relationship between Work engagement and affective commitment to change.

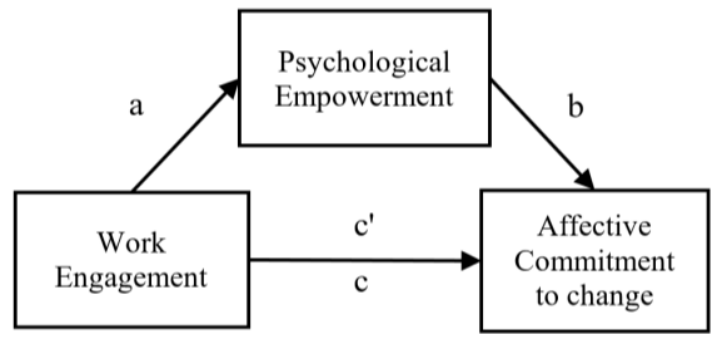

Figure 1 Relation of work engagement, psychological empowerment on affective commitment to change

\section{METHODS}

\subsection{Data Collection}

Data was collected through online questionnaires for a week, 23 - 30 march 2019. In this regard, we used the questionnaires as follows: Affective Commitment to change from Herscovitch and Meyer, Psychological Empowerment, and work engagement using Utrecht Work Engagement Scale (UWES)-9 [4], [28]. The details are shown in Table 1.

Table 1 Reliability of Measurement

\begin{tabular}{|l|c|c|}
\hline \multicolumn{1}{|c|}{ Name of Scale } & $\begin{array}{c}\text { Total } \\
\text { Item }\end{array}$ & Reliability \\
\hline $\begin{array}{l}\text { Affective commitment to } \\
\text { change }\end{array}$ & 6 & $\alpha=.70$ \\
\hline Psychological Empowerment & 12 & $\alpha=.85$ \\
\hline Work engagement & 15 & $\alpha=.88$ \\
\hline
\end{tabular}

\subsection{Measurement}

Measurement of Affective commitment to change using Commitment to Change Inventory from Herscovitch and Meyer consisting of 5 items [4]. The measurement of this variable using a Likert scale of 1-5 (1 = Very unlikely, $6=$ Very likely) with a Cronbach's Alpha coefficient of 0.70 . Measurement of psychological empowerment using modified ppsychological empowerment scale (PES) of Spreitzer consisting of 16 items [18]. The measurement of this variable using a Likert scale of 1-5 (1 = Very unlikely, $6=$ Very likely) with a Cronbach's Alpha coefficient of 0.85. Measurement of work engagement using Utrecht Work Engagement Scale (UWES)-9 that was modified and translate to Indonesia languages consisted of 15 items using a Likert-type scale ranging from $0-6(0=$ Never, $6=$ Always) with a Cronbach's Alpha coefficient of 0.88 . 


\subsection{Participants and procedures}

Participants were operational employees who work in an airport area. Characteristics of respondents are as follows, permanent staff, worked at least one year in the company, at least graduated from high school and has to experience organizational change. Questionnaires distribute online with all participants were 198 participants. Present profile demography of participants consisted of $64.6 \%$ male and $35.4 \%$ female, majority range of age within $25-44$ years old, majority educational attainment levels are senior high school $(88.4 \%)$, tenure less than 2 years $(92.4 \%)$ and position as staff $(79.8 \%)$. The resume demography profile of the participants can be seen in Table 2 .

Table 2 Demographic profile

\begin{tabular}{|c|c|c|}
\hline Characteristics & $\mathrm{N}$ & $\%$ \\
\hline Gender & & \\
\hline Male & 128 & 64.6 \\
\hline Female & 70 & 35.4 \\
\hline Age & & \\
\hline$<25$ Years & 79 & 39.9 \\
\hline $25-44$ Years & 105 & 53.0 \\
\hline$>44$ Years & 14 & 7.1 \\
\hline Education & & \\
\hline Senior High School & 175 & 88.4 \\
\hline Diplome 3 & 5 & 2.5 \\
\hline Bachelor & 18 & 9.1 \\
\hline Position & & 79.8 \\
\hline Staff & 158 & 17.2 \\
\hline Supervisor & 34 & 3.0 \\
\hline Middle Management & 6 & \\
\hline Tenure & & 92.4 \\
\hline$<2$ years & 183 & 6.6 \\
\hline 2 - 10 years & 13 & 1.0 \\
\hline$>10$ years & 2 & \\
\hline
\end{tabular}

\subsection{Data analysis}

Data were analyzed using Pearson's Correlation, and Hayes Process Macro v.3.0.

\section{RESULT AND DISCUSSION}

\subsection{Pre-eliminary analysis}

The objective of this research was to test the relation among psychological empowerment, work engagement and affective commitment to change. Table 3 (three) shows the result of the descriptive statistics and Pearson correlation. The results revealed that the mean of Work engagement was $5.16(\mathrm{SD}=.61)$, indicating that the employees have a high work engagement. The Mean of Psychological empowerment was $4,94 \quad(\mathrm{SD}=.57)$, this score also indicating that employees have a good perception of psychological empowerment. Mean for affective commitment to change was $4.59(\mathrm{SD}=.88)$, this score of means are above average (score 1 to 6 ) which showed that they have quite affective commitment to change. In addition to that, each of the variable has the mean score greater than 3 (three).

The result of correlation of all variables was positively and significantly. Psychological empowerment and affective commitment to change are positively significant $(\mathrm{r}=.17$, $\rho<0.05$ ), thus it indicated that employee who has high psychological empowerment most likely has a good affective commitment to change. This result supported hypotheses 1. Furthermore, results also showed that the correlation between work engagement and psychological empowerment were positive and significant $(\mathrm{r}=.45$, $\rho<0.01$ ), so employee with a good work engagement has a good feeling in employee empowerment. These results supported hypotheses 2 (two). Correlation between work engagement and affective commitment to change is positively and significant $(r=.20, \rho<0.01)$, indicating that employee with a high work engagement have a high affective commitment to change. We also analyze the demographic variables such as age, education, position and tenure for the 3 (three) variables. In this research we found that the elation of those variables and demographic factor were not significant.

Table 3 Statistics summary and correlations among variables and demographic

\begin{tabular}{|l|c|c|l|l|l|}
\hline \multicolumn{1}{|c|}{ Variable } & \multicolumn{1}{c|}{$\mathrm{M}$} & $\mathrm{SD}$ & \multicolumn{1}{c|}{1} & \multicolumn{1}{c|}{2} & 3 \\
\hline $\begin{array}{l}\text { Affective Commitment } \\
\text { to change }\end{array}$ & 4.59 & .88 & 1 & & \\
\hline $\begin{array}{l}\text { Psychological } \\
\text { empowerment }\end{array}$ & 4.94 & .57 & $.17^{*}$ & 1 & \\
\hline Work Engagement & 5.16 & .61 & $.20^{* *}$ & $.45^{* *}$ & 1 \\
\hline Age & 1.67 & .63 & -.01 & .00 & .00 \\
\hline Gender & 1.35 & .48 & -.06 & -.09 & -.09 \\
\hline Education & 1.21 & .59 & .07 & .03 & .00 \\
\hline Position & 1.23 & .49 & .13 &.-01 & .02 \\
\hline Tenure & 1.09 & .31 & .13 & .02 & -.05 \\
\hline
\end{tabular}

**. Correlation is significant at the 0.05 level (2-tailed).

** Correlation is significant at the 0.01 level (2-tailed).

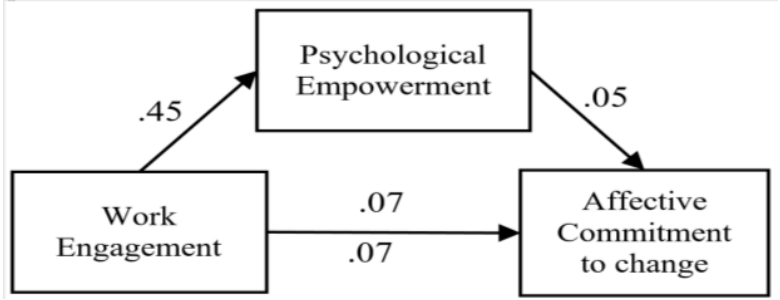

Figure 2 Relation of work engagement and psychological empowerment on affective commitment to change after using Hayes proses 


\subsection{Mediation analysis}

To analyze the role mediator of psychological empowerment in a relation of work engagement and affective commitment to change, we used Hayes Process Macro v.3.0. As shown in table 5 (five) from data process of Hayes, the relation between work engagement and psychological empowerment was significant $(\beta=.45$, $\rho<0.01$ ), but the relation between psychological empowerment and affective commitment to change was not significant $(\beta=.0 .05, \rho>0.05)$. Further, results also showed that the relationship between work engagement and affective commitment to change is significant is not significant $(\beta=.07, \rho>0.05)$. Indirect effect found -.01 to .60 , thus psychological empowerment was not proven as a mediator between work engagement and affective commitment to change. This does not support the hypothesis 3 .

Table 5 Results of the mediation analysis of psychological empowerment in the relationship between work engagement and affective commitment to change

\begin{tabular}{|l|c|c|c|c|c|}
\hline & \multirow{2}{*}{ Effect } & \multirow{2}{*}{ SE } & \multirow{2}{*}{$\rho$} & \multicolumn{2}{|c|}{ BC Bootstrap 95\% } \\
\cline { 4 - 6 } & & & & Lower & Upper \\
\hline $\begin{array}{l}\text { Direct Effect on } \\
\text { Work } \\
\text { Engagement }\end{array}$ & .07 & .04 & .054 & -.001 & .146 \\
\hline Indirect Effect & .02 & .02 & & -.001 & .157 \\
\hline
\end{tabular}

\subsection{Discussion}

The results showed that there are positive and significant correlation between work engagement and psychological engagement. This finding supported the previous study by Stander and Rothmann, Mufidah and Mangundjaya [47], [50]. These findings also supported Mangundjaya which showed that psychological empowerment became the critical in the development of commitment to change, Mangundjaya also stated that to face organizational change, organizational members would have self-confidence, feeling of self-efficacy [10], [20]. Others research conducted by Rindang and Mangundjaya showed that commitment to change had influenced by psychological empowerment [52].

The Correlation of work engagement to affective commitment to change is positive and significant. This result supported the previous researched by Yalabik et al. [53]. This finding also supported by Nadeem et al. engagement was correlated positively with affective commitment to change [11].

One of the objective this research was testing mediation role of psychological empowerment on work engagement to affective commitment to change. Meanwhile, psychological empowerment has not proven to become mediation of work engagement and affective commitment to change on this research. This means that improving work engagement or improving psychological empowerment can improve affective commitment to change. However, improving both work engagement and psychological empowerment did not give significant effect to affective commitment to change.

Limitations of this research are as follows: first, data collection of this research was collected through selfreports/questionnaires which might create some potential bias and do not supported through other data collection methods. Self-report measures in this cross-sectional also cause limitation of the generalization findings and inferences of causality. Second, this research was taken from one organization and only one business type. Further study is recommended to be conduct in different type of organizations.

\section{CONCLUSION}

Based on the results of this research, the following conclusions can be drawn: First, the variable Psychological empowerment has a positive and significant influence on affective commitment to change so that the first hypothesis is proven. Second, the variable work engagement has a positive and significant influence on psychological empowerment, so the second hypothesis is proven. Third, the Work engagement variable has a positive and significant influence on affective commitment to change so that the third hypothesis is proven. Fourth, the variable psychological empowerment as a mediator between work engagement and affective commitment to change is not proven.

\section{REFERENCES}

[1] W. L. Mangundjaya, "Leadership, empowerment, and trust on affective commitment to change in state-owned organisations," Int. J. Public Sect. Perform. Manag., vol. 5, no. 1, p. 46, 2019.

[2] M. Higgs and D. Rowland, "Leading change in a global organisation: Choices and Dilemmas," Int. Conf. Hum. Resour., no. February, pp. 1-16, 2007.

[3] G. Jacobs, A. Van Witteloostuijn, and J. ChristeZeyse, "A theoretical framework of organizational change," J. Organ. Chang. Manag., vol. 26, no. 5, pp. 772-792, 2013.

[4] L. Herscovitch and J. P. Meyer, "Commitment to organizational change: Extension of a threecomponent model," J. Appl. Psychol., vol. 87, no. 3, pp. 474-487, 2002.

[5] O. K. Harfoushi, R. F. Obiedat, and S. S. Khasawneh, "E-Learning Adoption Inside Jordanian Organizations From Change Management Perspective," Int. J. Emerg. Technol. Learn., vol. 5, no. 2, pp. 49-60, 2010. 
[6] P. Neves, "Organizational cynicism: Spillover effects on supervisor-subordinate relationships and performance," Leadersh. Q., vol. 23, no. 5, pp. 965-976, 2012.

[7] W. L. Mangundjaya and D. Giovanita, "Transformational Leadership, Change SelfEfficacy on Affective Commitment to Change, in Banking versus Insurance Industries," $A d v$. Sci. Lett., vol. 24, pp. 497-499, 2018.

[8] W. L. H. Mangundjaya, "The Role of Communication, Trust and Justice in Commitment to Change," Int. Conf. Business, Manag. Corp. Soc. Responsib., pp. 74-77, 2014.

[9] J. T. Parish, S. Cadwallader, and P. Busch, "Want to, need to, ought to: Employee commitment to organizational change," J. Organ. Chang. Manag., vol. 21, no. 1, pp. 32-52, 2008.

[10] W. L. Mangundjaya, "The Role of employee engagement on the commitment to change (during large-scale organizational change in Indonesia)," Int. J. Multidiscip. Thought, vol. 4, no. October, pp. 375-384, 2014.

[11] K. Nadeem, W. Akram, H. F. Ali, Y. Iftikhar, and W. Shamshad, "The Relationship between Work Values , Affective Commitment , Emotional Intelligence, and Employee Engagement: A Moderated Mediation Model," vol. 8, no. 3, pp. 469-482, 2019.

[12] S. Beijer and J. Gruen, "Employee Engagement During An Organisational Change," Stockholm University, 2016.

[13] Z. Y. Yalabik, P. Popaitoon, J. A. Chowne, and B. A. Rayton, "Work engagement as a mediator between employee attitudes and outcomes," Int. J. Hum. Resour. Manag., vol. 24, no. 14, pp. 27992823, 2013.

[14] M. A. Siddiqi, "Examining Work Engagement as a Precursor to Turnover Intentions of Service Employees," Int. J. Information, Bus. Manag., vol. 5, no. 4, pp. 118-132, 2013.

[15] F. Ölcer and M. S. Florescu, "Mediating effect of job satisfaction in the relationship between psychological empowerment and job performance," Theor. Appl. Econ., vol. 22, no. 3, pp. 111-136, 2015.

[16] M. O. R. A. Patah, S. M. Radzi, R. Abdullah, A.
Adzmy, R. A. Zain, and N. Derani, "The Influence of Psychological Empowerment on Overall Job Satisfaction of Front Office Receptionists," Int. J. Bus. Manag., vol. 4, no. 11, pp. 167-176, 2009.

[17] S. E. Seibert, S. R. Silver, and W. A. Randolph, "Taking Empowerment to The Next Level: A Multiple-Level Model of Empowerment , Performance, And Satisfaction," Acad. Manag. J., vol. 47, no. 3, pp. 332-349, 2004.

[18] G. M. Spreitzer, "Psychological Empowerment in the Workplace: Dimensions, Measurement, and Validation," Acad. Manag. J., vol. 38, no. 5, pp. 1442-1465, 1995.

[19] A. J. S. Morin, J. P. Meyer, É. Bélanger, J. S. Boudrias, M. Gagné, and P. D. Parker, "Longitudinal associations between employees' beliefs about the quality of the change management process, affective commitment to change and psychological empowerment," Hum. Relations, vol. 69 , no. 3 , pp. 839-867, 2016.

[20] N. Nuhanisa Radian and W. L. Mangundjaya, "Individual Readiness for Change as Mediator between Transformational Leadership and Commitment Affective to Change," J. Manaj. Aset Infrastruktur Fasilitas, vol. 3, no. 1, pp. 1-12, 2019.

[21]R. D. Foster, "Resistance, Justice, and Commitment to Change," Hum. Reources Dev. Q., vol. 21 , no. $1,2010$.

[22] J. T. Perish, S. Cadwallader, and P. Busch, "Want to, Need to, Ought to: Employee Commitment to Organizational Change,," J. Organ. Chang. Manag., vol. 21, no. 1, p. 32, 2008.

[23] B. Schneider, A. B. Yost, A. Kropp, C. Kind, and H. Lam, "Workforce engagement: What it is, what drives it, and why it matters for organizational performance," J. Organ. Behav., vol. 39, no. 4, pp. 462-480, 2018.

[24] A. B. Bakker, "Strategic and proactive approaches to work engagement," Organ. Dyn., vol. 46, no. 2, pp. 67-75, 2017.

[25] W. B. Schaufeli, "Work Engagement: A Key Concept of a Positive Occupational Health Psychology ?," Wellness Work. Conf., 2011.

[26] E. Bell and N. Barkhuizen, "The relationship between barriers to change and the work 
engagement of employees in a South African property management company," SA J. Ind. Psychol., vol. 37, no. 1, pp. 1-11, 2011.

[27] L. V. Ivanitskaya, S. Glazer, D. A. Erofeev, and J. A. Johnson, Group dynamics. Health organizations: Theory, behavior, and development. 2009.

[28] W. Schaufeli and A. Bakker, "Utrecht Work Engagement Scale (UWES): Preliminary manual, Version, 1.," no. December, 2004.

[29] S. L. Albrecht and M. Andreetta, "The influence of empowering leadership, empowerment and engagement on affective commitment and turnover intentions in community health service workers: Test of a model," Leadersh. Heal. Serv., vol. 24, no. 3, pp. 228-237, 2011.

[30] D. L. Strom, K. L. Sears, and K. M. Kelly, "Work Engagement: The Roles of Organizational Justice and Leadership Style in Predicting Engagement Among Employees," J. Leadersh. Organ. Stud., vol. 21, no. 1, pp. 71-82, 2014.

[31] T. L. Robbins, M. D. Crino, and L. D. Fredendall, "An integrative model of the empowerment process," Hum. Resour. Manag. Rev., vol. 12, no. 3, pp. 419-443, 2002.

[32] A. Khan, "Women and paid work in Pakistan: Pathways of women's empowerment," South Asia Res. Program. Pakistan Scoping Pap., 2007.

[33] G. Spreitzer, "Giving peace a chance: Organizational leadership, empowerment, and peace," J. Organ. Behav., vol. 28, pp. 1077-1095, 2007.

[34] D. R. May, R. L. Gilson, and L. M. Harter, "The psychological conditions of meaningfulness, safety and availability and the engagement of the human spirit at work," J. Occup. Organ. Psychol., vol. 77, pp. 11-77, 2004.

[35] B. J. Avolio, W. Zhu, W. Koh, and P. Bhatia, "Transformational leadership and organizational commitment: Mediating role of psychological empowerment and moderating role of structural distance," J. Organ. Behav., vol. 25, no. 8, pp. 951-968, 2004.

[36] D. L. Nelson and B. L. Simmons, "Health psychology and work stress: A more positive approach.," Handb. Occup. Heal. Psychol., pp. 97-
119, 2004.

[37] A. Olivier and S. Rothmann, "Antecedents of work engagement in a multinational oil company," SA J. Ind. Psychol., vol. 33, no. 3, pp. 49-56, 2007.

[38] R. M. Ryan and E. L. Deci, "On Happiness and Human Potentials: A Review of Research on Hedonic and Eudaimonic Well-Being," Annu. Rev. Psychol., vol. 52, no. 1, pp. 141-166, 2001.

[39] R. M. Ryan, V. Huta, and E. L. Deci, "Living well: A self-determination theory perspective on eudaimonia," J. Happiness Stud., vol. 9, no. 1, pp. 139-170, 2008.

[40] S. Llorens, W. Schaufeli, A. Bakker, and M. Salanova, "Does a positive gain spiral of resources, efficacy beliefs and engagement exist?," Comput. Human Behav., vol. 23, no. 1, pp. 825-841, 2007.

[41] C. Maslach, W. B. Schaufeli, and M. P. Leiter, "JOB BURNOUT," Annu. Rev., vol. 52, pp. 397422,2001

[42] G. M. Spreitzer, M. A. Kizilos, and S. W. Nason, "A dimensional analysis of the relationship between psychological empowerment and effectiveness, satisfaction, and strain," J. Manage., vol. 23, no. 5, pp. 679-704, 1997.

[43] P. Masvaure and J. H. Buitendach, "Validation of the work engagement, job satisfaction, psychological empowerment, and organisational citizenship measures in a mining sector setting in Zimbabwe," J. Psychol. Africa, vol. 29, no. 3, pp. 223-229, 2019.

[44] G. A. Yukl and W. S. Becker, "Effective Empowerment in Organizations," Organ. Manag. J., vol. 3, no. 3, pp. 210-231, 2006.

[45] R. Zeffane and H. A. M. Al Zarooni, "Empowerment, Trust and Commitment: The Moderating Role of Work-Unit Centrality," Int. J. Manag., vol. 29, no. 1, p. 332, 2012.

[46] Y.-O. Choong, K.-L. Wong, and T.-C. Lau, "Psychological empowerment and organizational commitment in the Malaysian private higher education institutions: A review and research agenda," Acad. Res. Int., vol. 1, no. 3, p. 236, 2011.

[47] M. W. Stander and S. Rothmann, "Psychological empowerment, job insecurity and employee engagement," SA J. Ind. Psychol., vol. 36, no. 1, 
pp. 1-8, 2010.

[48] J. Bhatnagar, "Management of innovation: role of psychological empowerment, work engagement and turnover intention in the Indian context," Int. J. Hum. Resour. Manag., vol. 23, no. 5, pp. 928-951, 2012.

[49] A. B. Bakker, E. Demerouti, and A. I. Sanz-Vergel, "Burnout and Work Engagement: The JD-R Approach," Annu. Rev. Organ. Psychol. Organ. Behav., vol. 1, no. 1, pp. 389-411, 2014.

[50] M. Mufidah and W. L. Mangundjaya, "The Impact of Psychological Capital and Psychological Empowerment on Employee ' s Affective Commitment to Change," Glob. J. Bus. Soc. Sci. Rev., vol. 6, no. 1, pp. 9-14, 2018.

[51] W. L. Mangundjaya, "Psychological empowerment and organizational task environment in commitment to change," Int. J. Bus. Manag., vol. II, no. 2, pp. 119-126, 2014.

[52] W. Rindang, A., \& Mangundjaya, "The impact of individual perception to organizational readiness for change, individual readiness for change and psychologicalempowerment toward the commitment to organizational change International APIO Conference," in APIO International Conference, 2013, vol. 5.

[53] Z. Y. Yalabik, Y. van Rossenberg, N. Kinnie, and J. Swart, "Engaged and committed? The relationship between work engagement and commitment in professional service firms," Int. J. Hum. Resour. Manag., vol. 26, no. 12, pp. 1602 1621, 2015. 